\title{
Hubungan antara Aktivitas Fisik dan Konsumsi Zat Besi dengan Status Gizi pada Remaja Putri di SMP Yayasan Pendidikan Islam Bintaro Jakarta Selatan Tahun 2017
}

\author{
Ernyasih $^{1}$ Siti Riptifah Tri Handari ${ }^{2}$ \\ ${ }^{1,2}$ Program Studi Kesehatan Masyarakat, Fakultas Kesehatan Masyarakat \\ Universitas Muhammadiyah Jakarta \\ ummi_rifali@yahoo.com, ndari_drh@yahoo.com
}

\begin{abstract}
ABSTRAK
Pola konsumsi berhubungan dengan status gizi, konsumsi pangan remaja perlu diperhatikan karena pertumbuhan yang sangat cepat, sehingga kebutuhan pertumbuhan dan aktivitas juga meningkat. lebih dari sepertiga remaja putri mengalami anemia di 21 dari 41 negara. Jika berbagai aktifitas fisik dan pertumbuhan meningkat tidak diimbangi dengan masukan zat gizi yang cukup maka tubuh akan mengalami masalah gizi (malnutrisi). Tujuan penelitian ini adalah diketahuinya hubungan aktivitas fisik, pola makan dengan status gizi pada remaja putri di SMP Yayasan Pendidikan Islam Bintaro Jakarta Selatan. Penelitian ini merupakan penelitian kuantitatif dengan desain studi cross sectional. Penelitian ini dilakukan di SMP Yayasan Pendidikan Islam Bintaro Jakarta Selatan dan pengumpulan data dilakukan pada bulan Pebruari sampai April 2018. Populasi pada penelitian ini adalah 260 siswi dengan sampel 76 siswi. Analisis data menggunakan univariat dan bivariat menggunakan chi-square. Hasil penelitian menunjukan bahwa Responden yang beraktivitas ringan (71.1\%), aktivitas sedang (17.1\%) dan aktivitas tinggi (11.8\%). Pola makan responden yang jarang mengkonsumsi sumber heme $(67.1 \%)$, sering $(32.9 \%)$ jarang mengkonsumsi sumber non-heme (59.2\%), sering (40.8\%), jarang mengkonsumsi penghambat zat besi 63.2\%), sering $(36.8 \%)$, pernah mengkonsumsi suplemen zat besi $(2,6 \%)$, tidak pernah $(97.4 \%)$. Status gizi kurang $(40.8 \%)$, normal $(48.7 \%)$, lebih $(10.5 \%)$. Tidak ada hubungan antara aktivitas fisik dengan status gizi ( $\mathrm{p}$ value 0.298), tidak ada hubungan antara konsumsi sumber zat non-heme dengan status gizi (p value 0.627), tidak ada hubungan antara konsumsi penghambat zat besi dengan status gizi (p value 0.762), tidak ada hubungan antara konsumsi suplemen zat besi dengan status gizi ( $\mathrm{p}$ value 0.130). Hasil analisis menunjukkan bahwa terdapat hubungan antara konsumsi sumber zat heme dengan status gizi (p value 0.016). Zat besi heme akan mempengaruhi status gizi karena zat besi yang berasal dari bahan makanan hewani (zat besi heme) mempunyai tingkat absorpsi 20-30\%. Besi heme lebih mudah diserap dan penyerapannya tidak tergantung dengan zat makanan lainnya.
\end{abstract}

Kata Kunci: Status Gizi, Aktivitas Fisik, Pola Makan, Remaja

\begin{abstract}
The consumption pattern is related to nutritional status, adolescent food consumption needs to be considered because of very rapid growth, so that the need for growth and activity also increases. More than a third of girls experience anemia in 21 of 41 countries. If various physical activities and increased growth are not matched by adequate input of nutrients, the body will experience nutritional problems (malnutrition). The purpose of this study was to find out the relationship of physical activity, diet with nutritional status in young women in the Bintaro Yayasan Pendidikan Islam Junior High School in Bintaro South Jakarta. This study was a quantitative study with cross-sectional design. It was conducted in the Yayasan Pendidikan Islam Junior High School in Bintaro South Jakarta and collection conducted in February until April 2018. The population in this study were 260 female students with a sample of 76 female students. The data analysis was used univariate and bivariate analysis (Chisquare test). Respondents who performed light activities $(71.1 \%)$, moderate activity $(17.1 \%)$ and high activity $(11.8 \%)$. Dietary patterns of respondents who rarely consumed sources of heme $(67.1 \%)$, often $(32.9 \%)$ rarely consumed non-heme sources $(59.2 \%)$, often $(40.8 \%)$, rarely consumed iron barriers $(63.2 \%)$, often $(36.8 \%)$, ever taking iron supplements (2.6\%), never (97.4\%). Poor nutritional status (40.8\%), normal (48.7\%), more (10.5\%). There is no correlation between physical activity and nutritional status ( $\mathrm{p}$ value 0.298 ), there is no correlation between the consumption of non-heme substances with nutritional status ( $p$ value 0.627 ), there was no correlation between consumption of iron inhibitors and nutritional status ( $\mathrm{p}$ value 0.762 ), there was no correlation between consumption of iron supplements and nutritional status ( $p$ value 0.130$)$. The result showed there was a correlation between the consumption of the source of the heme substance and nutritional status ( $\mathrm{p}$ value 0.016). Heme iron will affect nutritional status because iron derived from animal food ingredients (heme iron) has an absorption rate of $20-30 \%$. Heme iron is more easily absorbed and its absorption is not dependent on other food substances.
\end{abstract}

Keywords: Nutritional Status, Physical Activity, Diet, Youth 


\section{Pendahuluan}

Remaja merupakan periode perubahan fisiologis, psikologis, dan kognitif yang terjadi pada masa anak-anak menjadi dewasa muda. Masa remaja disebut juga dengan masa pubertas, artinya masa ketika anak mula mengalami kematangan secara seksual dan organ reproduksi siap untuk menjalankan fungsinya. Masa pubertas remaja putri umumnya terjadi pada usia 8-13 tahun. Masa pubertas disebabkan oleh adanya perubahan hormonal. Hormon tersebut dihasilkan oleh kelenjar endokrin yang dikontrol oleh susunan saraf pusat, khususnya dihipotalamus ${ }^{1}$.

Selama masa remaja terjadi perkembangan identitas pribadi, sistem nilai moral dan etika, harga diri, persepsi body image dan kesadaran seksualitas serta masalah psikososial. Perubahan dramatis bentuk tubuh dan ukuran tubuh menyebabkan banyak terjadi di kalangan remaja, yang mengarah ke pengembangan citra tubuh yang buruk dan gangguan makan ${ }^{2}$.

Menurut Survei Studi Diet Total tahun 2014, sebagian besar penduduk di Indonesia memiliki tingkat kecukupan energi sangat kurang dan kurang yaitu sebesar $79.6 \%$, terdiri dari $45.7 \%$ penduduk dengan tingkat kecukupan energi sangat kurang/minimal dan $33.9 \%$ penduduk dengan tingkat kecukupan energi kurang. Berdasarkan karakteristik umur, kelompok umur remaja (13-18 tahun) tingkat kecukupan $52.5 \%$ gizi sangat kurang dan $30.3 \%$ kurang ${ }^{3}$.

Salah satu yang berhubungan dengan status gizi adalah pola konsumsi. Pola konsumsi remaja perlu diperhatikan karena pertumbuhan yang sangat cepat, sehingga kebutuhan pertumbuhan dan aktivitas juga meningkat. Jika berbagai aktifitas fisik dan pertumbuhan meningkat tidak diimbangi dengan masukan zat gizi yang cukup maka tubuh akan mengalami masalah gizi (Malnutrisi) $^{4}$.

Faktor lain yang berhubungan adalah aktivitas fisik. Aktivitas fisik sama artinya dengan aktivitas eksternal merupakan sesuatu yang mnggunakan tenaga atau energi untuk melakukan berbagai kegiatan fisik seperti berjalan, berolahraga, berlari dan lain sebagainya. Aktivitas fisik telah diidentifikasi sebagai faktor utama keempat untuk kematian global (6\% dari kematian global) ${ }^{5}$. Berdasarkan Riskesdas 2013, diketahui aktivitas fisik tergolong kurang aktif secara umum adalah 26.1\%. DKI Jakarta termasuk ke dalam provinsi dengan penduduk aktivitas fisik tergolong kurang aktif berada di atas rata-rata Indonesia dan menduduki lima tertinggi dengan presentase $44.2 \%{ }^{6}$.

SMP Yayasan Pendidikan Islam Bintaro Jakarta Selatan merupakan salah satu tempat pendidikan yang berada di wilayah DKI Jakarta, yang memiliki siswi yang berpotensi mempunyai aktivitas fisik yang kurang. Penelitian ini bertujuan untuk mengetahui hubungan aktivitas fisik, pola makan dan status gizi pada remaja putri di SMP Yayasan Pendidikan Islam (YPI) Bintaro Jakarta Selatan

\section{Metode}

Penelitian ini merupakan penelitian analitik kuantitatif dengan pendekatan Cross sectional. Penelitian ini dilakukan pada remaja 
Ernyasih, Siti Riptifah Tri Handari. Hubungan Antara Aktivitas Fisik Dan Konsumsi Zat Besi Dengan Status Gizi Pada Remaja Putri Di Smp Yayasan Pendidikan Islam Bintaro Jakarta Selatan.

DOI :

putri di SMP Yayasan Pendidikan Islam Bintaro Jakarta Selatan pada bulan FebuariApril 2018. Populasi dalam penelitian ini adalah seluruh remaja putri yang bersekolah di SMP YPI Bintaro Jakarta Selatan yaitu 260 siswi. Sampel dalam populasi diambil secara simple random sampling sejumlah 76 siswi yaitu kelas VII sejumlah 36 siswi, kelas VIII sejumlah 16 siswi dan kelas IX sejumlah 24 siswi. Variabel yang diteliti adalah aktivitas fisik dan pola makan dengan status gizi remaja putri di SMP Yayasan Pendidikan Islam Bintaro Jakarta Selatan.

Pengambilan data dalam penelitian ini dilakukan dengan pengukuran IMT/U untuk mengetahui status gizi setiap responden. Alat yang digunakan berupa timbangan injak berat badan (bathromm scale) untuk menimbang berat badan dan microtoa untuk mengukur tinggi badan. Selain itu penelitian juga menggunakan kuesioner untuk memperoleh informasi dari responden dalam arti laporan tentang pribadinya atau hal-hal yang ia ketahui serta FFQ (Food Frequency Questionnare.

Pengolahan data dilakukan melalui beberapa tahapan untuk kemudian dilakukan analisis secara univariat dan bivariat. Analisis univariat dilakukan untuk melihat gambaran aktivitas fisik dan pola makan selama tujuh hari dengan status gizi remaja putri di SMP Yayasan Pendidikan Islam Bintaro Jakarta Selatan. Analisis bivariat digunakan untuk mengetahui hubungan antara variabel dependen yaitu status gizi dengan variabel independen yaitu aktivitas fisik dan pola makan (konsumsi sumber zat heme, konsumsi sumber zat non-heme, konsumsi penghambat zat besi, konsumsi suplemen zat besi)

\section{Hasil}

Pada tabel 1 menunjukkan hasil univariat dari penelitian. Responden menurut aktivitas fisik sebagian besar adalah beraktivitas ringan yaitu sebanyak 54 orang (71.1\%). Sedangkan responden menurut kebiasaan konsumsi sumber heme merata untuk masing-masing perilaku konsumsi sumber heme jarang sebanyak 38 orang $(50.0 \%)$ dan perilaku konsumsi sumber heme sering sebanyak 38 orang $(50.0 \%)$. Distribusi responden menurut kebiasaan sumber non-heme lebih banyak responden yang jarang memiliki kebiasaan mengkonsumsi sumber non-heme yaitu sebanyak 45 orang (59.2\%). Distribusi responden menurut kebiasaan konsumsi penghambat zat besi lebih banyak responden yang jarang memiliki kebiasaan mengkonsumsi penghambat zat besi yaitu sebanyak 48 orang (63.2\%). Distribusi responden menurut kebiasaan konsumsi suplemen zat besi sebagian besar tidak pernah mengkonsumsi suplemen zat besi yaitu sebanyak 74 orang (97.4\%). Responden menurut status gizi, lebih banyak responden dengan status gizi normal yaitu sebanyak 37 orang (48.7\%). 
Tabel 1. Hasil Univariat

\begin{tabular}{ccc}
\hline Variabel & Jumlah & Persentase \\
\hline 1. Aktivitas Fisik & 54 & 71.1 \\
Ringan & 13 & 17.1 \\
Sedang & 9 & 11.8 \\
Tinggi & & \\
2. Pola Makan & & \\
Kebiasaan Konsumsi Sumber Heme & 51 & $67.1 \%$ \\
Jarang & 25 & $32.9 \%$ \\
Sering & & \\
Kebiasaan Konsumsi Sumber Non-Heme & 45 & $59.2 \%$ \\
Jarang & 31 & $40.8 \%$ \\
Sering & 48 & $63.2 \%$ \\
Kebiasaan Konsumsi Penghambat Zat Besi & $36.8 \%$ \\
Jarang & 28 & \\
Sering & & $2.6 \%$ \\
Pernah & 2 & $97.4 \%$ \\
Konsumsi Suplemen Zat Besi & 74 & 40.8 \\
Tidak Pernah & & 48.7 \\
K. Status Gizi & 31 & 10.5 \\
Kurang & 37 & $\mathbf{1 0 0}$ \\
Normal & 8 & \\
Lebih & $\mathbf{7 6}$ &
\end{tabular}

Hasil pada tabel menunjukkan tidak ada hubungan antara aktivitas fisik dengan status gizi ( $p$ value 0.298). Terdapat hubungan antara kebiasaan konsumsi sumber zat heme dengan status gizi ( $p$ value 0.016$)$ dan responden yang jarang mengkonsumsi sumber zat heme lebih banyak (51.0\%). Tidak ada hubungan antara konsumsi sumber zat non-heme dengan status gizi ( $p$ value 0.627) dan yang jarang mengkonsumsi sumber zat non-heme mempunyai gizi kurang (40.0\%). Peneliti juga menemukan tidak ada hubungan antara konsumsi penghambat zat besi dengan status gizi ( $p$ value 0.762) dan yang sering mengkonsumsi penghambat zat besi mempunyai gizi normal 47.9\%. Tidak ada hubungan antara konsumsi suplemen zat besi dengan status ( $p$ value 0.130 yang responden yang tidak pernah mengkonsumsi suplemen zat besi mempunyai status gizi normal (50.09\%). 
Ernyasih, Siti Riptifah Tri Handari. Hubungan Antara Aktivitas Fisik Dan Konsumsi Zat Besi Dengan Status Gizi Pada Remaja Putri Di Smp Yayasan Pendidikan Islam Bintaro Jakarta Selatan.

DOI :

Tabel 2. Hasil Bivariat

\begin{tabular}{|c|c|c|c|c|c|c|c|c|c|}
\hline \multirow[t]{3}{*}{ Aktivitas Fisik } & \multicolumn{6}{|c|}{ Status Gizi } & \multirow{2}{*}{\multicolumn{2}{|c|}{ Total }} & \multirow[t]{3}{*}{ p value } \\
\hline & \multicolumn{2}{|c|}{ Kurang } & \multicolumn{2}{|c|}{ Normal } & \multicolumn{2}{|c|}{ Lebih } & & & \\
\hline & $\mathbf{n}$ & $\%$ & $\mathbf{n}$ & $\%$ & $\mathbf{n}$ & $\%$ & $\mathbf{N}$ & $\%$ & \\
\hline Ringan & 26 & 48.1 & 23 & 42.6 & 5 & 9.3 & 54 & 100 & 0,298 \\
\hline Sedang & 2 & 15.4 & 9 & 68.2 & 2 & 15.4 & 13 & 100 & \\
\hline Berat & 3 & 33.3 & 5 & 55.6 & 1 & 11.1 & 9 & 100 & \\
\hline \multicolumn{10}{|l|}{ Pola Makan } \\
\hline \multicolumn{10}{|c|}{ Konsumsi Sumber Zat Heme } \\
\hline Jarang & 26 & 51.0 & 19 & 37.3 & 6 & 11.8 & 51 & 100 & \multirow[t]{2}{*}{0.016} \\
\hline Sering & 5 & 20.0 & 18 & 72.0 & 2 & 8.0 & 25 & 100 & \\
\hline \multicolumn{9}{|c|}{ Konsumsi Sumber Zat Non-Heme } & \multirow{3}{*}{0.627} \\
\hline Jarang & 18 & 40.0 & 21 & 46.7 & 6 & 13.3 & 45 & 100 & \\
\hline Sering & 13 & 41.9 & 16 & 51.6 & 2 & 6.5 & 31 & 100 & \\
\hline \multicolumn{10}{|c|}{ Konsumsi Penghambat Zat Besi } \\
\hline Jarang & 19 & 39.6 & 23 & 47.9 & 6 & 12.5 & 48 & 100 & \multirow[t]{2}{*}{0.762} \\
\hline Sering & 12 & 42.9 & 14 & 50.0 & 2 & 7.1 & 28 & 100 & \\
\hline \multicolumn{9}{|c|}{ Konsumsi Suplemen Zat Besi } & \multirow{3}{*}{0.130} \\
\hline Pernah & 1 & 50.0 & 0 & 0 & 1 & 50.0 & 2 & 100 & \\
\hline Tidak Pernah & 30 & 40.5 & 37 & 50.0 & 7 & 9.5 & 74 & 100 & \\
\hline
\end{tabular}

\section{Pembahasan}

Masa remaja merupakan salah satu periode dari perkembangan manusia. Masa ini merupakan masa perubahan atau peralihan dari masa kanak-kanak ke masa dewasa yang meliputi perubahan biologik, perubahan psikologik, dan perubahan sosial. Di sebagian besar masyarakat dan budaya masa remaja pada umumnya dimulai pada usia 10-13 tahun dan berakhir pada usia 18-22 tahun ${ }^{7}$.

Responden menurut aktivitas fisik sebagian besar adalah beraktivitas ringan yaitu sebanyak 54 orang (71.1\%). Aktivitas fisik adalah gerakan anggota tubuh yang diproduksi oleh kontraksi otot sehingga menghasilkan tenaga yang berfungsi untuk pemeliharaan kesehatan fisik dan mental serta mempertahankan kualitas hidup agar tetap sehat dan bugar sepanjang hari. Menurut Akmal (2012) aktivitas fisik dapat dibagi menjadi tiga yaitu, aktivitas fisik ringan, sedang dan berat. Beberapa faktor yang mempengaruhi aktivitas fisik remaja adalah umur, pola makan dan penyakit ${ }^{8}$.

Dampak yang ditimbulkan dari kurangnya aktivitas fisik adalah menyebabkan penurunan kebugaran, selain itu keterbatasan aktivitas fisik juga menyebabkan seseorang mengalami kelebihan berat badan. Berat badan berlebih disebabkan peningkatan timbunan energi dalam bentuk jaringan lemak, biasanya pada rongga perut atau pinggul, akibat penurunan penggunaan energi ${ }^{9}$.

Tidak ada hubungan yang signifikan antara aktivitas fisik dengan status gizi, ( $p$ value $=0.298)$, serta responden lebih banyak dengan aktivitas fisik ringan dengan status gizi kurang (48.1\%). Hal ini tidak sesuai dengan hasil penelitian Merinta (2012) tentang hubungan body image, pengetahuan tentang gizi 
dan aktivitas fisik pada mahasiswa poltekes di Papua dimana hasilnya menunjukan bahwa aktivitas fisik yang dilakukan secara rutin dapat mempertahankan status gizi optimal.

Berdasarkan hasil uji statistik menunjukkan bahwa ada hubungan antara konsumsi sumber zat heme berupa daging dengan status gizi ( $p$ value 0.016). Zat besi heme akan mempengaruhi status gizi karena zat besi yang berasal dari bahan makanan hewani (zat besi heme) mempunyai tingkat absorpsi 20$30 \%$. Besi heme lebih mudah diserap dan penyerapannya tidak tergantung dengan zat makanan lainnya ${ }^{10}$. Brooker (2001) menjelaskan besi heme yaitu besi yang berasal dari hemoglobin dan myoglobin yang hanya terdapat dalam bahan makanan hewani seperti daging, ikan dan ungags. Bioavailabilitas besi heme ini sangat tinggi yaitu $20-30 \%$ atau lebih dapat diabsorpsi ${ }^{11}$.

Berdasarkan hasil uji statistik menunjukkan bahwa tidak ada hubungan antara konsumsi sumber zat non-heme dengan status gizi ( $p$ value 0.672). Kemungkinan hasil penelitian ini kurang bermakna karena tidak diketahuinya besar porsi dalam sekali makan dalam satu hari, dimana pada penelitian ini hanya ditanyakan dalam setahun ini berapa kali mengkonsumsi makanan sumber zat non-heme. Tidak ada hubungan antara konsumsi penghambat Zat Besi (Teh dan Kopi) dengan kejadian status gizi ( $p$ value 0.762). Faktor penghambat $\mathrm{Fe}$ bukanlah hanya seputar pada teh dan kopi yang mengandung tannin saja, namun banyak sekali zat-zat yang dapat menghambat penyerapan $\mathrm{Fe}$ meliputi phosvitin dalam kuning telur, protein kedelai, phytat, asam folat, kalsium dan serat dalam bahan makanan, zat-zat gizi ini dengan zat besi membentuk senyawa yang tidak larut dalam air, sehingga sulit untuk di absorbsi. Protein nabati maupun protein hewani tidak meningkatkan absorbsi besi ${ }^{12}$.

Berdasarkan hasil uji statistik menunjukkan bahwa tidak ada hubungan antara konsumsi suplemen zat besi dengan status gizi ( $p$ value 0.130). Hasil yang tidak bermakna antara konsumsi suplemen zat besi dengan status gizi remaja kemungkinan karena tingkat pengetahuan remaja putri remdah mengenai suplemen zat besi masih rendah dan masih menganggap zat besi hanya dibutuhkan bagi ibu hamil saja. Hal ini sesuai dengan teori yang dikemukakan oleh Suhardjo (2003) yang menyatakan penyebab penting dari gangguan gizi selain kemiskinan dan persediaan pangan adalah kurangnya pengetahuan tentang gizi atau kemampuan untuk menerapkan informasi tersebut dalam kehidupan sehari-hari ${ }^{13}$.

\section{Kesimpulan}

Tidak ada hubungan antara ativitas fisik, perilaku konsumsi (kebiasaan konsumsi sumber non heme, kebiasaan konsumsi penghambat zat besi dan konsumsi suplemen zat besi). Ada hubungan antara konsumsi sumber zat heme dengan status gizi $(p$ value $=$ 0.016). 
Ernyasih, Siti Riptifah Tri Handari. Hubungan Antara Aktivitas Fisik Dan Konsumsi Zat Besi Dengan Status Gizi Pada Remaja Putri Di Smp Yayasan Pendidikan Islam Bintaro Jakarta Selatan.

DOI :

\section{Daftar Pustaka}

1. Sarwono, Sarlito W. 2015. Psikologi Remaja. Rajawali Pers PT Raja Grafindo Persada

2. Brown, Judith E. et. al. 2013. Nutrition throught The Life Cycle. Wadsworth: USA

3. Kementrian kesehatan RI. 2015. Profil kesehatan Indonesia tahun 2015. Kemenkes, jakarta.

4. Arisman. 2010. Gizi dalam daur Kehidupan. Jakarta Penerbit Buku Kedokteran EGC.

5. Soetjiningsih, 2010. Tumbuh Kembang Remaja dan Permasalahnnya. Penerbit CV Sagung Seto

6. Kementrian kesehatan RI. 2013. Riskesdas 2013. Kemenkes, jakarta.
7. Notoatmodjo Soekidjo, 2007. Ilmu Perilaku Kesehatan. PT. Rineka Cipta

8. Akmal, F, Hilda. 2012. Perbedaan Asupan Energi, Protein, Aktivitas Fisik Dan Status Gizi Antara Lansia Yang Mengikuti Dan Tidak Mengikuti Senam Bugar Lansia.

9. Barasi, M. Marry. 2009. At a Galance Ilmu Gizi. PT gelora Aksara Pratama

10. Merinta. 2012. Hubungan Body image, Pengetahuan gizi seimbang, dan aktivitas fisik terhadap status gizi mahasiswa poiteknik Kesehatan jayapura.

11. Brooker C. 2001. Kamus Saku Keperawatan. Jakarta: ECG

12. Achmad Djaeni. 2000. Ilmu Gizi untuk Mahasiswa Profesi Di Indonesia. Jakarta : Dian Rakyat.

13. Suhardjo. 2003. Sosio Budaya Gizi. Bogor : Direjen Dikti, Pusat Antar Universitas Pangan dan Gizi. 